\title{
Article \\ Information and Communication Technology (ICT) Utilization and Infrastructure Alignment in Construction Organizations
}

\author{
Hassan Khames Eliwa ${ }^{1, *(\mathbb{D}}$, Mostafa Babaeian Jelodar ${ }^{1, *(\mathbb{D})}$ and Mani Poshdar ${ }^{2}(\mathbb{D})$ \\ 1 School of Built Environment, Massey University, Auckland 0745, New Zealand \\ 2 School of Future Environments, Auckland University of Technology, Auckland 1142, New Zealand; \\ mani.poshdar@aut.ac.nz \\ * Correspondence: h.k.eliwa@massey.ac.nz (H.K.E.); m.b.jelodar@massey.ac.nz (M.B.J.)
}

check for updates

Citation: Eliwa, H.K.; Jelodar, M.B. Poshdar, M. Information and Communication Technology (ICT) Utilization and Infrastructure Alignment in Construction Organizations. Buildings 2022, 12, 281 https://doi.org/10.3390/ buildings 12030281

Academic Editor: Bo Xia

Received: 31 December 2021

Accepted: 18 February 2022

Published: 1 March 2022

Publisher's Note: MDPI stays neutral with regard to jurisdictional claims in published maps and institutional affiliations.

Copyright: (C) 2022 by the authors. Licensee MDPI, Basel, Switzerland. This article is an open access article distributed under the terms and conditions of the Creative Commons Attribution (CC BY) license (https:// creativecommons.org/licenses/by/ $4.0 /)$.

\begin{abstract}
Information and communication technology (ICT) is one of the important factors that support construction project performance. Various studies have concluded that by aligning the ICT utilization with organizational ICT infrastructure, better performance outcomes can be achieved from the project to organization level. A positive connection between utilization of ICT and project performance has been established. However, the effects of ICT utilization strategy alignment with the organizational ICT infrastructure on construction project performance have not been investigated. This research evaluates and analyzes the importance of organizational ICT infrastructure to improve ICT utilization not just at the project level but also at the level of construction organizations. The main objective of this research is to investigate whether the effect of ICT utilization on project performance may be restricted and affected by its alignment with the ICT infrastructure level in the organization. The analyses of ICT infrastructure, ICT usage, and their associations with project performance are based on case studies of projects and organizations from the New Zealand construction sector. A method of evaluating ICT utilization and ICT infrastructure is proposed. This allows for further detailed examination of the strategic alignment between ICT utilization and organizational infrastructure. The effects of this strategic alignment on project performance are discussed and recommendations for the optimal strategic utilization are provided.
\end{abstract}

Keywords: information and communication technology; ICT; ICT infrastructure; ICT utilization; construction management; construction organizations; project performance

\section{Introduction}

The construction sector is considered as one of the biggest investment-draining sectors worldwide, with extremely high influence and contribution to economic development [1-4]. However, this sector faces considerable barriers and challenges, such as low performance, frequent construction delays, quality issues and cost overruns [4]. Therefore, finding solutions to improve construction project performance and make the project management knowledge more efficient is the main challenge for organizations to achieve client requirements $[4,5]$. One of these solutions is to apply new technologies and implement effective information and communication technology (ICT) applications in construction projects $[4,6]$.

ICT can be described as technologies involved in the collection, transport, retrieval, storage, access, presentation, and transformation of all forms of information [7]. ICT can also be defined as applying information and communication technology tools, including software and computer hardware [8,9]. On the other hand, ICT infrastructure can be defined as the necessary components to manage and operate enterprise IT environments [10,11]. An organization can deploy its IT infrastructure in a cloud computing environment or computer facilities. These components include hardware and software, as well as networking and operating systems (OS), which are all used to provide IT services and solutions [11]. 
ICT utilization is crucial in the support of project operations, and the organizational ICT infrastructure supports the performance of ICT implementation from the project level to the organization level [12,13]. Moreover, many construction companies have turned to ICT utilization to quickly respond to changes in the environment and owners' demands [13,14]. The creation of new and innovative processes for projects is one major way ICT can add value to an organization's performance. In addition, if there is a strong ICT infrastructure within an organization, IT can enhance coordination, communication, cooperation, and collaboration among team members [15]. Although some research has suggested a positive correlation between ICT implementation and organizational performance, little empirical research has concentrated on the alignment between the ICT organizational infrastructure and the ICT utilization [12,15]. These studies focus on the impact of IT infrastructure on projects and capital facilities or infrastructure performance [13,15]. To date, there are only limited studies on the adoption of ICT by construction organizations, and fewer studies regarding the effects of strong alignment of the ICT infrastructures and ICT utilization on organization performance. This is considering the relatively long period of time that computer integration has been advocated in construction literature [16].

Based on the available literature, there is a lack of information and evidence about the business value of ICT utilization in the construction industry. This scarcity of evidence could be why ICT usage, especially for project processes, seems limited [16,17]. Therefore, it is important to study how this ICT usage impacts project team-owner relationships, general organization outcomes, and the success of construction projects. However, ITC utilization alone is not the perfect solution with a utilization strategy. Accordingly, the ICT infrastructure alignment is crucial to the overall organization's performance $[3,12,18]$.

Accordingly, this study aims to explain the relationship between the utilization of ICT, organizational ICT infrastructure, and construction project performance. The first research question is: How does the availability of ICT infrastructure in the construction organization support and improve the utilization of ICT? This may be one of the factors in improving the outcomes of the construction project; therefore, the second question is: How can the alignment between the ICT infrastructure and ICT utilization affect project performance? The main objective of this study is to investigate whether the effect of ICT utilization on project performance may be moderated and affected by the ICT infrastructure level in the organization. This study highlights the importance of an organizational ICT infrastructure for enhancing its usage. It also indirectly provides guidelines to improve capital construction organization and project performance.

\section{Background: Construction ICT Utilization}

A significant number of studies have been conducted on ICT adoption in the construction industry and its relation to construction project performance [19-22]. These studies generally cover ICT utilization and factors that influence its implementation as part of the construction management process. It also discusses the expected benefits of using ICT in project management and construction [20-23]. Considering the type of ICT usage, Rahimian et al. (2020) examined the extent to which ICT, in general, is being used in the execution of construction industry projects. On the other hand, Elghaish et al. (2020) investigated the potential of a specific ICT, the 4D BIM technology, as a productive tool in project management. Sharma et al. (2020) provided a valuation model that measures the utility of electronic networking technologies as a type of ICT in construction project activities' progress. Alsafouri et al. (2018) also addressed the crucial issue of how to best utilize ICT in construction industry organizations. Ozumba et al. (2018) conducted a detailed case study to examine the role ICT transfer plays in innovation in medium- to small-sized construction organizations.

Other authors are also active in identifying the factors that influence the adoption and use of ICT [24-26]. J. Li et al. (2020) looked at the relationship between construction equipment ICT and construction management progress. They ended up with three factors that mainly determine the impact of equipment ICT benefits, which are ICT implementation 
control, ICT implementation acceptance, and the project condition [27]. Daniotti et al. (2020) suggested that a lack of information about ICT and its benefits and an unclear competitive advantage may have caused a construction management team to resent adopting new technologies. Osunsanmi et al. (2020) concluded that the ICT adoption process is mainly linked to client relationship management. According to Adafin et al. (2021), New Zealand's construction sector has increasingly utilized ICT in the design and the project operational phase, resulting in unstructured and discrete utilization strategies. Conversely, the construction management and onsite construction execution phases had the lowest ICT utilization levels in New Zealand's construction industry. Moreover, in the New Zealand construction industry, ICT utilization was most widespread in the second phase (design phase) and less widespread during the fourth phase (project management phase) $[2,28,29]$.

Many studies believe that ICT can provide significant benefits and contribute to construction project performance. However, it depends on the implementation methods [3,30-32]. There is limited research on the construction industry that has studied the impact of ICT on the performance of the construction organization, and the existing focus is on the project, as opposed to organization, performance [33]. Adriaanse et al. (2010), Hosseini et al. (2012), and Ozumba et al. (2018) are just a few examples of such studies. On the other hand, Hong et al. (2019) and Peansupap et al. (2005) are two other examples of studies that examined the current state of ICT use at the organization level. The work of Henderson et al. (2010) was one of the most comprehensive of these studies. They evaluated ICT's utilization on an organization's specified projects using the organization data. Henderson et al. (2010) used their evaluation to determine the impact of ICT usage on the cost of a project and its schedule success within the organizational processes and context. Boton et al. (2015) carried out a case study to show the feasibility of using technologies such as $4 \mathrm{D}$ BIM on a construction project considering the organization information. To identify potential problems, the research team examined the master critical path schedule method CPSM [34]. Afzal et al. (2021) claim that their case study demonstrates the value of 4D models for visualizing and understanding construction methodology, schedule sequencing, communicating special constraints to a project, and formalizing design information. They also argue that $4 \mathrm{D}$ models can be used to anticipate safety hazards and the assignment and allocation of project resources and construction-related machinery to the worksite, as well as for constructability reviews [35]. Alaloul et al. (2020) found that this visualization allows stakeholders of the construction projects to understand the construction schedule better than traditional construction management tools.

Howard et al. (2008) assessed ICT usage across design and construction organizations using the ICT barometer structured survey from the Finnish construction industry. Most organizations were mainly using computers for internal administrative and management tasks, including archiving. In contrast, fewer organizations use ICT tools to manage construction projects during delivery, or for document sharing and cloud usage [36]. Lu et al. (2019) conducted an empirical study analysis on construction industry cases and found similar results. They also reported widespread usage of basic ICT tools such as spreadsheets, accounting, word processing, and emailing. While a small number of organizations used advanced tools like 3D and 4D technology, according to Lu et al. (2019), larger organizations were using more of the most recent ICT tools compared with the medium- to small-sized organizations [37,38].

Based on the above statements, these studies were focusing on the specific types of ICT, mostly at a project level. They do not consider the benefits of adopting a wider range of ICT considering the organizational ICT infrastructure, organization innovation implementation strategy, and the organization ICT utilization experience. This research addresses this gap by investigating the impact of wide-range ICT utilization and organizational infrastructure alignment at both the organization and project levels. 


\section{Project Performance and ICT Infrastructure of Strategic Alignment}

Strategic alignment originates from the idea that ICT must be aligned with the business or organizational strategy to create a competitive advantage and achieve a higher utilization of ICT [39]. According to Avison et al. (2004), strategic alignment's core premise is that analyses using the traditional methods have tended to focus on the extent of that alignment process and the organization or firm's infrastructure strategy (which is known as strategic fit), or on the other hand, the extent to which ICT utilization supports the business's approach (which is known as functional integration). Henderson et al. (1999) state that organizations must consider strategic fit and functional integration to maximize their competitive advantage. Therefore, the strategic alignment concept is built on two basic building blocks: functional integration and strategic fit. There are internal and external domains within each of these blocks, as shown in Figure 1 [40,41].

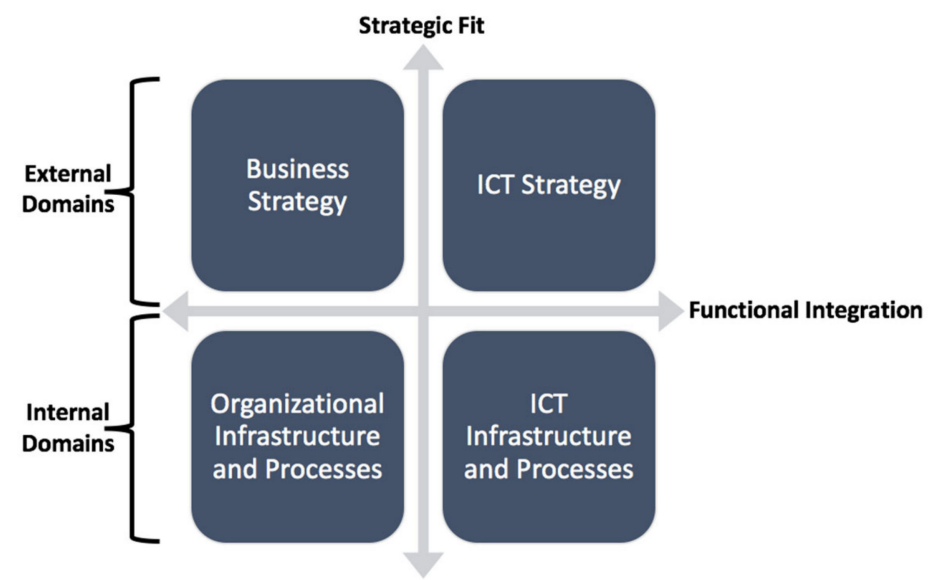

Figure 1. The strategic alignment model concept [40].

The external domain of ICT strategy is concerned with the positioning of the organization in the ICT market in terms of the ICT scope of the organization itself, the ICT implementation efficiency, and the organization's ICT implementation decision making. This domain can be identified as an ICT strategy [42]. Moreover, the internal domain is concerned with the configuration and management of the ICT infrastructure, including its processes, skills, and system structure. This domain can be identified as an ICT infrastructure domain $[39,43]$.

In general, the strategic alignment term aims to integrate the ICT domains and the business domains at the strategic level based on the relationship between the organization's ICT strategy and the organization's business strategy. In addition, it aims to integrate these at the operational level, which is related to the relationship between the ICT infrastructure and the organization's infrastructure [40]. To put the strategic alignment in place, we need to consider one of these four domains, which will drive the alignment between the next two domains [44]. This perspective, which is the basis of our study, is the "strategy execution", where the business strategy drives both the organizational work process and the ICT infrastructure $[3,44]$.

Isal et al. (2020) defined ICT infrastructure, with regard to the strategic alignment model, as any situation required to implement and utilize various ICT products or services. Based on this, ICT infrastructure can be the main factor that enables the organization to implement and establish effective ICT application services [45]. The ICT infrastructure component can be described in two parts. The first part is the hardware, which includes the tools, equipment, and machinery essential to operate a specific type of ICT. The second part is the software or the operating system, which provides the platform for operating the system hardware and includes all the applications and software that are necessary to run it $[42,46,47]$. Moreover, human resources and policy issues are critical components 
in terms of ICT utilization, and this is why it is important to have a supportive external environment [48].

Managing the organizational infrastructure is becoming more critical all over the globe, and a system is required to assess this management $[48,49]$ effectively. Considering project infrastructure as a child of the main organizational infrastructure, Wu et al. (2015) has focused on project infrastructure issues in terms of evaluating the organization's performance. Wu et al. (2015) argue that the project performance indicators must be clearly defined as a part of the organization management and control strategy. Kefi et al. (2005) investigated the previous statement using an empirical study. They highlighted the indicator system used to calculate construction project key performance. Kefi et al. (2005) noted that many of these indicators used in the case studies would not clearly describe the actual project performance. The stakeholders had declined these indicators as a system for the construction project's performance measurements considering the conditions of the projects.

However, organization management, project managers, and project delivery teams have strongly believed in the importance of developing project performance metrics to help achieve project goals [48,49]. Considering that, construction management teams always want to make informed decisions about the project performance indication, just like any other type of management [42]. Although there have been many studies on key performance frameworks for project measurements, there are not enough research studies to provide specific guidelines. There are no universally accepted principles for the performance measurements [44]. The problem is exacerbated in the construction sector as there are limited studies on IT and ICT alignment models for construction organizations. Therefore, we focus on assessing the alignment of ICT infrastructure for construction projects and respective organizations.

\section{The Research Methodology}

The selection of appropriate research methodology to satisfy the study objectives depends on multiple factors, such as the structure of the research questions and objectives, the level of the researcher's control of the data sources or the study condition, and the extent of the focus on historical rather than contemporary events [50]. Historical methods can be useful when the researcher does not control the data sources. Experiments are preferred if the researcher is directly, accurately, and systematically able to control the research behavior $[50,51]$. On the other hand, the use of the case study methodology is preferred if the research is about examining live or present events and the related behavior of this event cannot be controlled or changed [51]. In general, if the research questions are related to "why" and "how" and the researcher has limited control over the study cases, the case study methodology will be the best choice, which is the case in our research [50,51].

This research investigates the effects of alignment between the ICT infrastructure and ICT utilization on project performance. It adopts a case study method. However, it is important to select the right cases for the study to maximize the amount of information intake and learning within the study's limited timeframe [51]. In general, there are three case study methodology types: descriptive, exploratory, and explanatory [50]. This research is exploratory in nature and based on the research questions dealing with operational issues and events or links that require tracing and examining. According to Snyder [52], the case study approach highlights the problems that are difficult to describe based only on the data collected empirically. However, it is possible to design a study based on the case study methodology in a specific framework so that both secondary data (organization- and project-specific information) and primary data (ICT utilization and ICT infrastructure) are analyzed [50,52]. To summarize the above statements, this study is developed and applied as a qualitative exploratory case study methodology, which has been selected to gain a better investigation over the application of an ICT infrastructure alignment system at the organization and project levels [50,52]. 
Considering all the above, the justification of the case study method for this research is based on three main points. The first point is that this methodology allows comparison between two or more empirical cases in multiple situations based on the study conditions, selecting specific results for this comparison [52]. The second point is that this methodology allows the collection of detailed data which support the study's discussion process towards a theoretical conclusion, which is our plan for this study [52-54]. Finally, this methodology allows the researcher to study the operational and strategic engagement of the study cases in a specific location or area [52].

Accordingly, four construction projects within two different organizations in New Zealand were chosen. The selection of the cases and organizations were based on the following:

- The selected organizations have been considered from the top 10 major construction organizations in the infrastructure and building fields of New Zealand.

- Both organizations have declared ICT implementations strategies and have histories of ICT adoption. Moreover, both selected organizations have a department for ICT research and innovation.

- All four case study projects are considered large infrastructure or building projects in the Auckland area.

- All four case study projects have been completed and are currently at the operational phase. The final project data have been archived in the organization as the company's projects history.

A framework of multiple case study analysis has been developed and presented in Figure 2. The framework demonstrates the relationship between the organizations and project cases selected for this study in addition to the detailed level of exploration [17]. As mentioned above, all case study projects have been completed, which means the period of the investigations can be defined as the whole life cycle of the projects. The Auckland region, the major region in New Zealand, has been considered during the case studies' location selection. It covers most of the national construction demand (NCD) in New Zealand. Moreover, the governmental investment in construction in the Auckland region increased to $\$ 17$ billion in 2021 compared with $\$ 12$ billion in 2015 , which is more than a $40 \%$ increase [1].

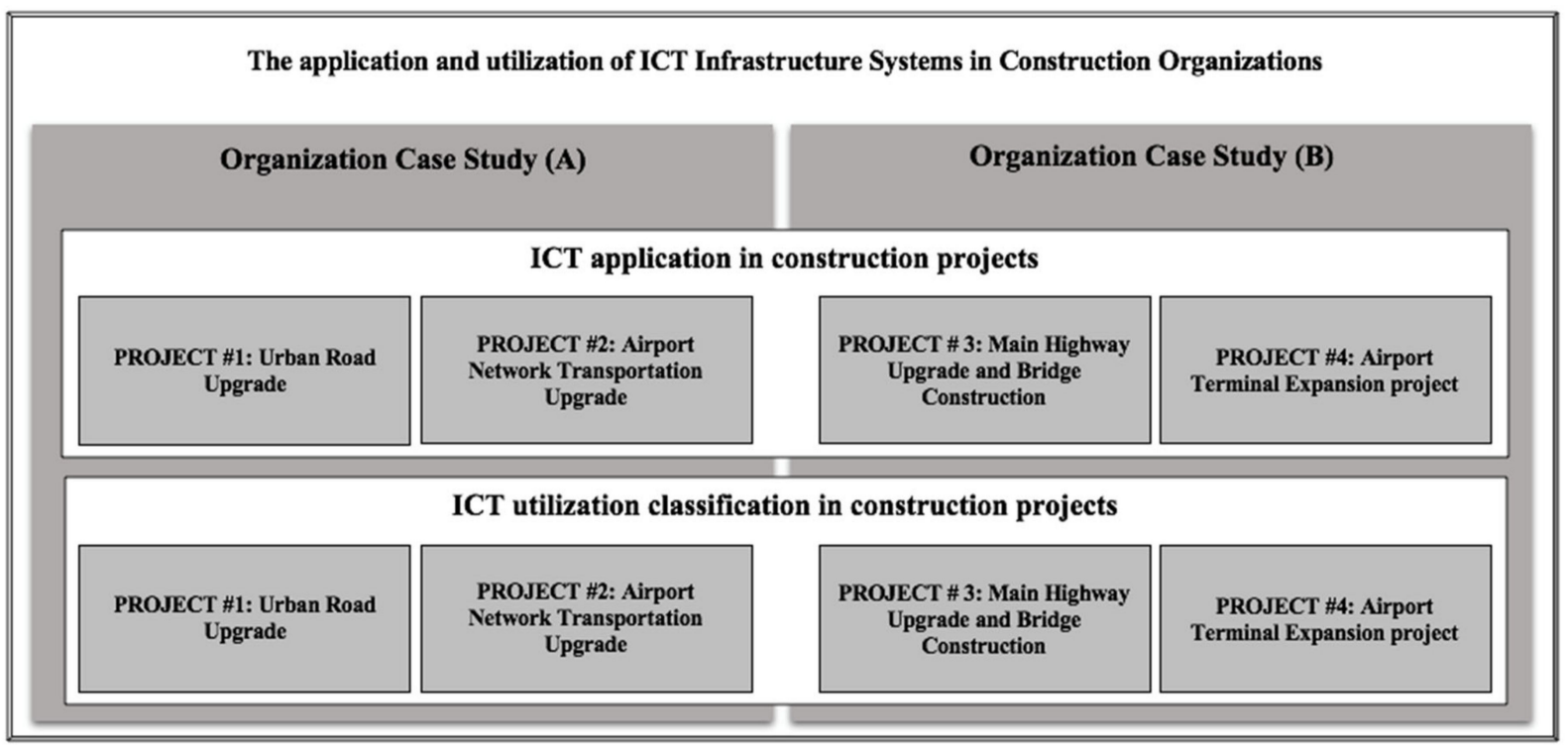

Figure 2. The case study methodology framework. 


\section{Data Collection}

The ICT implementation and utilization journey in the selected case study projects were examined based on the research question and objectives. The ICT infrastructure and innovation ability in the organizations hosting the selected projects were extracted from the organizations' ICT strategic documentation and policies. Finally, project progress history and performance records evaluated each project's outcomes and performance. It included examining the as-built documents, such as the as-built schedule compared with the baseline schedule of the project life cycle. Initially, an overview description of each organization and project selected for case studies is provided in this section. This is followed by a detailed evaluation of ICT utilization and ICT infrastructure data as well as the projects' performance data.

\subsection{Organization Case Study $(A)$}

The first selected organization for this study was one of the largest construction companies in New Zealand. It can be considered the largest construction services provider in New Zealand. They have been providing and delivering construction and engineering services in New Zealand, and especially to the Public Works Department, for decades. The organization has over 10,000 employees working in 120 locations in New Zealand and over 60,000 employees globally. Organization A has three main construction sectors: transportation or infrastructure (the main and biggest sector), utility service provision, and facilities management. The operating income for this organization in New Zealand has been estimated at over NZD 13 billion [1].

\subsection{Organization Case Study (B)}

The second case study organization in this research started in New Zealand in 1909, using a different name with their first project, a two-story wooden villa in Otago. The company has a strong history in New Zealand with their special and landmark project. In 1940, this organization's current name was born, and it was listed on the share market. The organization has over 4000 employees working in various locations around New Zealand, and it has international branches. During their history, this organization has completed over 90 major infrastructure and building projects, in addition to small- and medium-sized projects, all over New Zealand. Moreover, it has been identified as the first overseas organization working on the modernization and development of the South Pacific. It has permanent locations in Samoa, Tonga, Fiji, Vanuatu, New Guinea, and the Solomon Islands $[1,55,56]$.

\subsection{Project Case Study (1)}

The first project case study in this research is a project completed by organization A, the "Urban Road Upgrade" project. The project is a $9 \mathrm{~km}$ long infrastructure upgrade to improve the highway, including construction of bridges in Auckland (Figure 3). The project's total cost is over NZD 130 million. The final project duration up to the operational phase was 43 months, from June 2016 to December 2019. The main project scope was the widening works on the main motorway, including constructing additional bridge lanes, replacing the over-bridges, stormwater upgrade, and modification and upgrading of the cycleway $[57,58]$. 


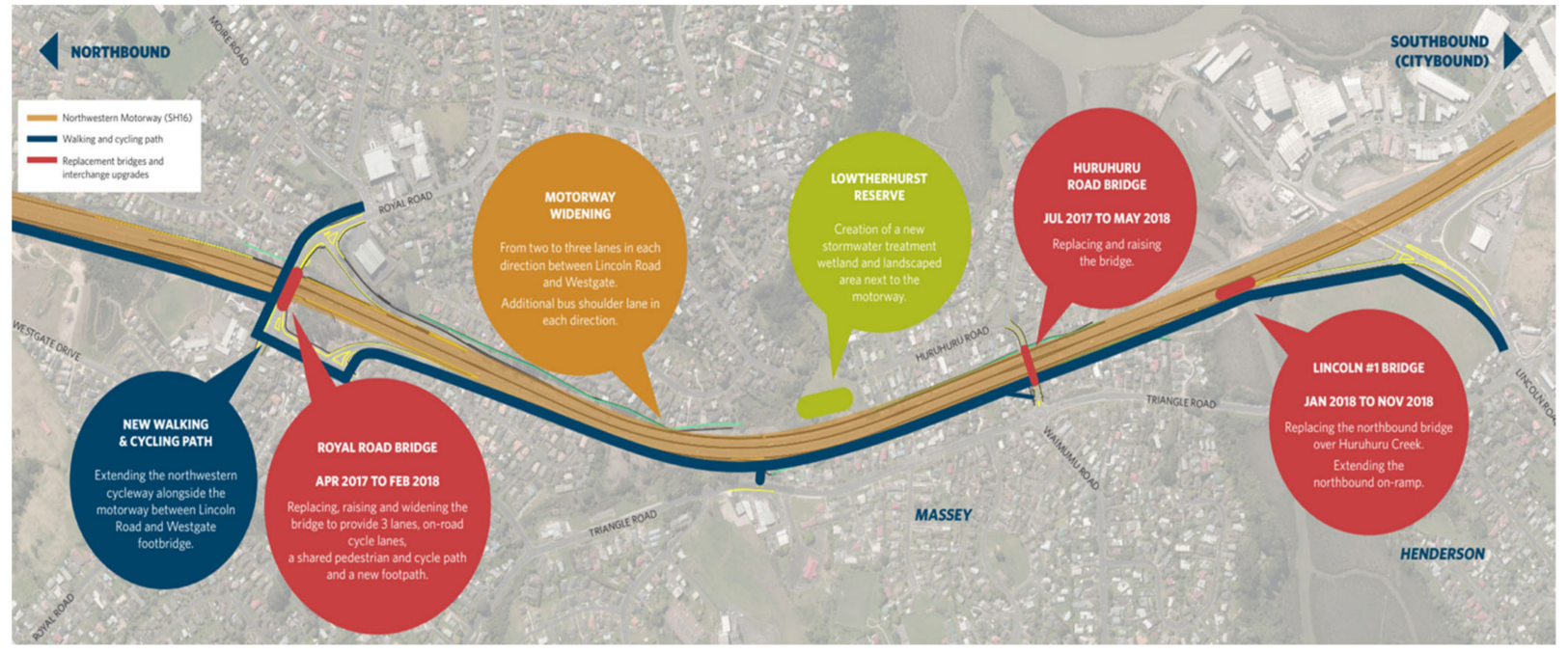

Figure 3. Urban Road Upgrade project plan [58].

\subsection{Project Case Study (2)}

The second project case study by organization A is "Airport Network Transportation Upgrade". This project is focused on upgrading the airport core road networks, including the main highway and new roads (Figure 4). The total cost of the project is over NZD 100 million, and the main purpose is to increase the road capacity leading to the biggest airport in New Zealand to over 200,000 vehicles a day. The main project scope was to widen the main motorway to the airport, decrease the pressure on the motorway by building new roads, upgrade the shared pathway, and upgrade the utilities and the stormwater lines. The total project duration up to the operational phase was about 26 months, from August 2019 to September $2021[59,60]$.

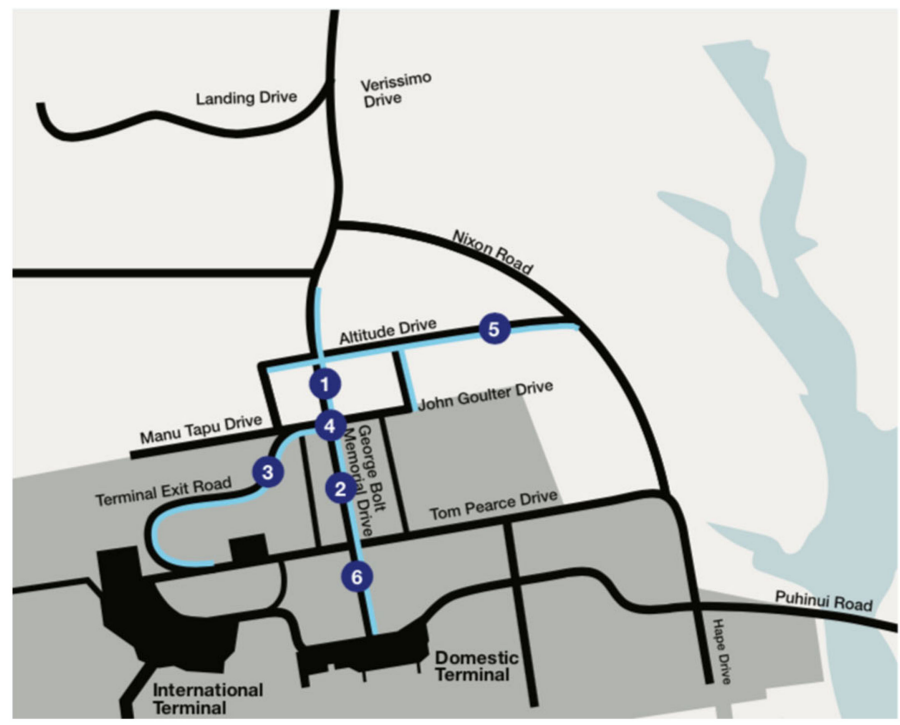

Northern Network

(1) Widening George Bolt Memorial Drive to add high occupancy vehicle

2 Enhanced pedestrian and shared pathway links

3 New one-way loop road from the international terminal to George Bolt Memorial Drive

(4) Two new traffic light-controlled intersections to improve traffic flows and allow pedestrians and cyclists to cross safely

(5) Altitude Drive will provide additional roading capacity, allowing terminal bound traffic greater joumey time reliability

6 Installing new underground utilities to create a resilient, future-proofed network able to support the wider terminal and runway developments

Figure 4. Airport Network Transportation Upgrade project [59].

\subsection{Project Case Study (3)}

The third project case study considered in this research is the "Main Highway Upgrade and Bridge Construction Project" by an alliance. A group of companies came together with the project client to deliver the project, sharing the project's profits and risks under the main contractor's management. Organization B was responsible for delivering the project extension from the south, related to the main tunnel construction, and from the 
north, related to the connection to the first project case study in this research, "Urban Road Upgrade". Organization B was also a supporter of the alliance in terms of providing IT infrastructure, provisional management consultation, and project coordination. The main project scope was to widen the main $5 \mathrm{~km}$ long motorway, and construct two bridges and a cycleway (Figure 5). The total project cost was over NZD 220 million, and the total project duration was 36 months, from November 2013 to December 2016 [61,62].

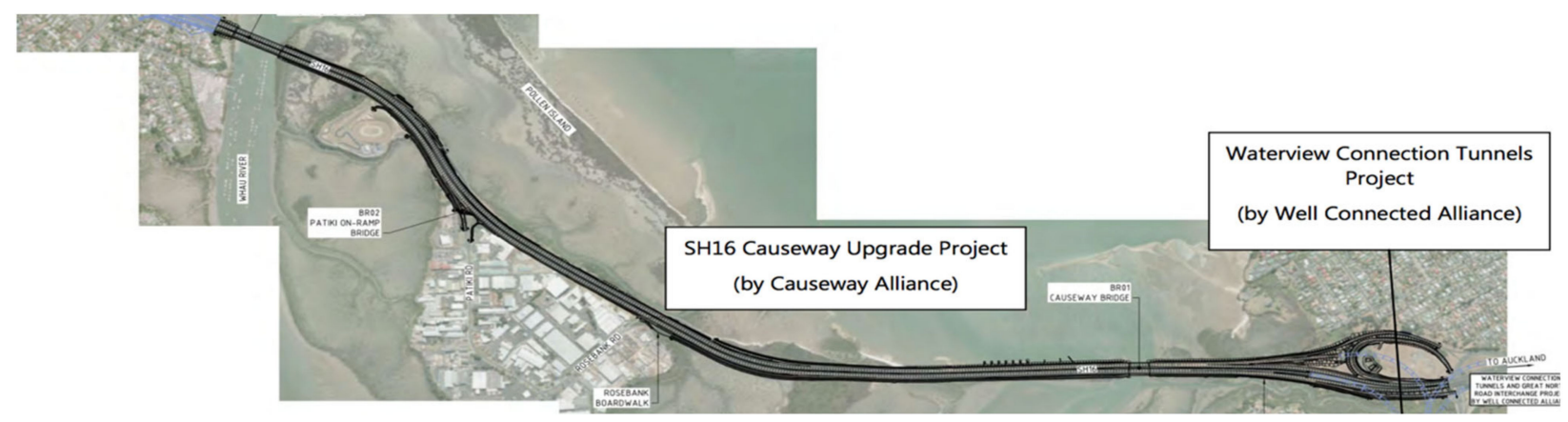

Figure 5. Main Highway Upgrade and Bridge Construction Project master plan [61].

\subsection{Project Case Study (4)}

The final case study in this research is the "Airport Terminal Expansion Project". Organization B was involved in this project, the biggest stage of the airport multistage development projects. It was focused on upgrading and developing the airport's international terminal building. The main project scope was constructing a new traveler processing hall, expanding the traveler lounge zone, reconfiguring the farewell zone, constructing a new security screening area, and major upgrading on the duty-free shopping spaces (Figure 6). The total project cost was NZD 220 million, and 32 months was the total duration of the project, from March 2016 to October 2018 [63].

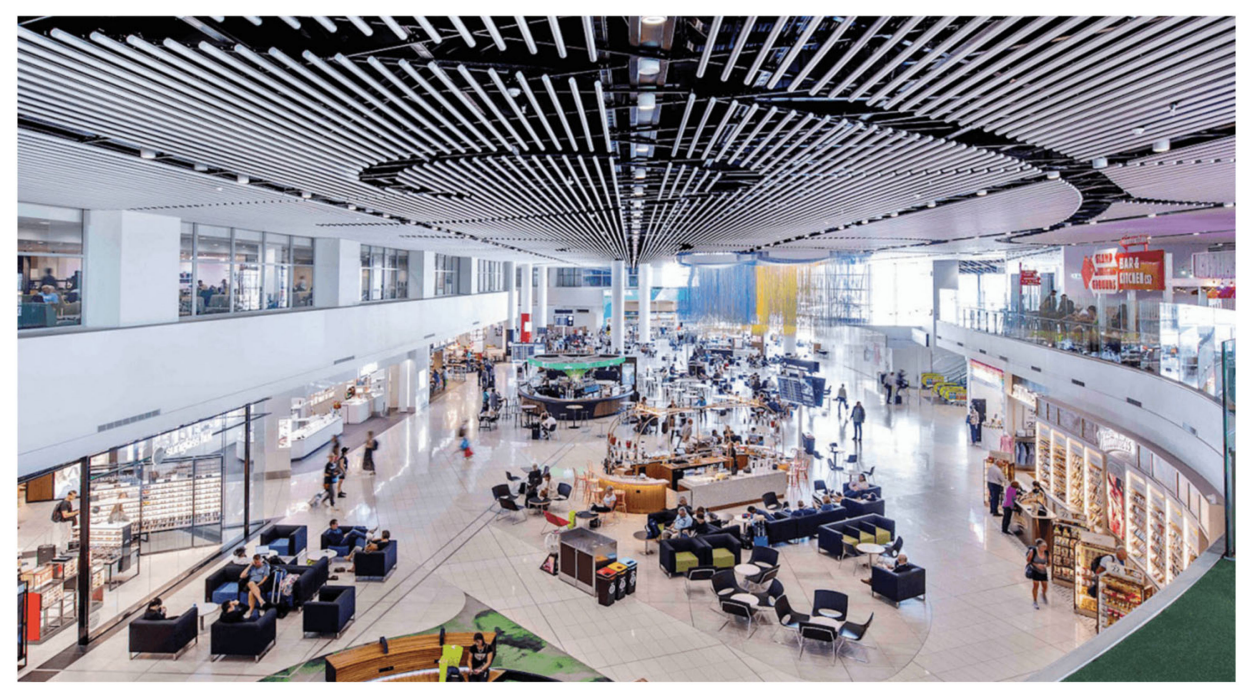

Figure 6. Airport Terminal Expansion Project—architectural elevation view [63].

\subsection{Data Collection of the Project Performances}

As mentioned above, the performance data for each case study project have been collected from the internal project history document, including but not limited to the as-built project schedule, monthly project reports, and organization performance report. Then, the final performance data for each case study have been grouped, arranged, and summarized, as shown in Table 1. 
Table 1. Projects case studies performance table.

\begin{tabular}{|c|c|c|c|c|c|c|c|c|c|c|c|}
\hline Project Name & $\begin{array}{l}\text { Actual Start } \\
\text { Date }\end{array}$ & $\begin{array}{l}\text { Actual } \\
\text { Completion } \\
\text { Date }\end{array}$ & $\begin{array}{l}\text { Baseline Finish } \\
\text { Date }\end{array}$ & $\begin{array}{c}\text { Actual } \\
\text { Duration }\end{array}$ & $\begin{array}{l}\text { Baseline } \\
\text { Duration }\end{array}$ & $\begin{array}{l}\text { Variance } \\
\text { Duration }\end{array}$ & $\begin{array}{l}\text { Non- } \\
\text { Compensable } \\
\text { Delay }\end{array}$ & $\begin{array}{c}\text { Compensable } \\
\text { Delay }\end{array}$ & $\begin{array}{l}\text { Pecentage of Non- } \\
\text { Compensable } \\
\text { Delay from the } \\
\text { Total Duration } \\
\end{array}$ & $\begin{array}{l}\text { Wet Weather } \\
\text { Risk Counted }\end{array}$ & Reasons of Compensable Delays \\
\hline $\begin{array}{l}\text { Project 1: Urban } \\
\text { Road Upgrade }\end{array}$ & 06 June 2016 & $\begin{array}{l}13 \text { December } \\
2019\end{array}$ & 31 May 2018 & 881 & 496 & -385 & -287 & -98 & $33 \%$ & Yes & $\begin{array}{l}4 \text { months approved time-cost } \\
\text { variation due to change part of the } \\
\text { retaining walls design }\end{array}$ \\
\hline $\begin{array}{l}\text { Project 2: } \\
\text { Airport Network } \\
\text { Transportation } \\
\text { Upgrade }\end{array}$ & 12 August 2019 & $\begin{array}{l}24 \text { September } \\
2021\end{array}$ & $\begin{array}{l}25 \text { February } \\
2021\end{array}$ & 531 & 386 & -145 & 0 & -145 & $0 \%$ & Yes & $\begin{array}{l}\text { The first reason was due to the } \\
\text { COVID-19 lockdown in 2020, and } \\
\text { then the Airport reduced the scope } \\
\text { of works for this project due to } \\
\text { financial issues due to the } \\
\text { lockdown. After that, the airport } \\
\text { started to return the original scope } \\
\text { back by stages }\end{array}$ \\
\hline $\begin{array}{l}\text { Project 3: Main } \\
\text { Highway } \\
\text { Upgrade and } \\
\text { Bridge } \\
\text { Construction } \\
\end{array}$ & $\begin{array}{l}\text { 04 November } \\
2013\end{array}$ & $\begin{array}{l}15 \text { December } \\
2016\end{array}$ & $\begin{array}{l}29 \text { February } \\
2016\end{array}$ & 779 & 580 & -199 & -51 & -148 & $7 \%$ & Yes & $\begin{array}{l}\text { Timber piles redesign requirement } \\
\text { related to ground improvement } \\
\text { requirement. Also, some of client } \\
\text { change requests }\end{array}$ \\
\hline $\begin{array}{l}\text { Project } 4 \text { : } \\
\text { Airport Terminal } \\
\text { Expansion } \\
\text { project }\end{array}$ & 07 March 2016 & 31 October 2018 & $\begin{array}{l}16 \text { February } \\
2018\end{array}$ & 663 & 487 & -176 & -48 & -128 & $8 \%$ & Not required & $\begin{array}{l}\text { The client approved some } \\
\text { variations due to design delay and } \\
\text { damaged materials due to } \\
\text { rainwater leaking through the } \\
\text { under-construction roof. Also, } \\
\text { some additional architectural } \\
\text { features requirements by the client }\end{array}$ \\
\hline
\end{tabular}


From Table 1, the total duration, baseline duration, and delays have been calculated using working days timescale, considering the local approved working calendars. Compensable delay is the delay that the client has accepted as not being the contractor's responsibility, such as the client's change in scope or design change. Moreover, the compensable delays only included the client's approved time and cost variation. The non-compensable delays are any internal delays, such as production rate, poor management, change in the project management, material procurement, or subcontractor issues. The inclement weather contingency was also considered and calculated in the project's schedule for every external infrastructure project, including most of the earthworks, structures, and pavement works, through a special wet weather calendar assignment or as a risk on the construction activity. Considering the wet weather calculation in the schedule will decrease the project delay risk due to heavy raining days.

\subsection{ICT Utilization and Organizational ICT Infrastructure}

As mentioned in the previous sections, the ICT infrastructure information has been exported from the organizations' internal documentation, especially from the innovation department in each organization. Table 2 summarizes the collected data regarding the level of ICT infrastructure from each of the organization case studies. From the table, the ICT infrastructure system has been classified. This classification considers the most critical factors that can affect the organizational ICT infrastructure level $[12,43,47,48,64]$, and the following classes have been derived:

- IC01: Data center infrastructure/hardware (including servers; storage subsystems; networking devices, such as switches, routers, and physical cabling; and dedicated network appliances, such as network firewalls)

- IC02: Internet infrastructure including fiber optic

- IC03: Cloud-based infrastructure

- IC04: Training systems

- IC05: ICT support systems

- IC06: Software upgrading systems

The rating system in Table 2 (High, Medium, and Low) has been developed to evaluate the level of application for each of the above-mentioned classes within the organization. Based on the rating system, if the organization is using the specific ICT class in all of its projects, the rating is considered as "High" for that specific class. If the organization is applying a specific class to more than $50 \%$ of its projects, the rating in this case has been considered as "Medium". Finally, if the application of a specific class by the organization in less than $20 \%$ of the organization's projects, the rating has been considered as "Low" in this case. 
Table 2. The organizational ICT infrastructure availability for each case study.

\begin{tabular}{|c|c|c|c|c|c|c|c|c|}
\hline & Organization Size & Organization Type & $\begin{array}{l}\text { Construction Services } \\
\text { Type }\end{array}$ & $\begin{array}{l}\text { Experience Level in } \\
\text { the Field }\end{array}$ & Avail & ICT In & tructure System in the Organization & $\begin{array}{l}\text { Project Case Study per } \\
\text { Organization }\end{array}$ \\
\hline \multirow{6}{*}{ Organisation A } & \multirow{6}{*}{$\begin{array}{l}\text { Large }>10,000 \\
\text { employees }\end{array}$} & \multirow{6}{*}{ Private/Contractor } & \multirow{6}{*}{ Civil \& Infrastructure } & \multirow{6}{*}{$\begin{array}{l}88 \text { years' experience in } \\
\text { the construction } \\
\text { industry in New } \\
\text { Zealand }\end{array}$} & IC01 & High & All applied & \multirow{6}{*}{$\begin{array}{l}\text { Project1: Urban Road Upgrade } \\
\text { Project 2: Airport Network } \\
\text { Transportation Upgrade }\end{array}$} \\
\hline & & & & & IC02 & High & All applied & \\
\hline & & & & & IC03 & High & Applied and setup in all projects & \\
\hline & & & & & IC04 & Low & $\begin{array}{l}\text { Technical training only and limited number of ICT } \\
\text { training for limited number of Staff categories }\end{array}$ & \\
\hline & & & & & IC05 & Low & $\begin{array}{l}\text { Very basic support system / support system for all } \\
\text { ICT is outsourcing }\end{array}$ & \\
\hline & & & & & IC06 & Low & $\begin{array}{l}\text { Very hard to get ICT software updated with a } \\
\text { complicated approval process before getting it } \\
\text { updated - Cost and budgeted issue }\end{array}$ & \\
\hline \multirow{6}{*}{ Organisation B } & \multirow{6}{*}{$\begin{array}{l}\text { Large }>4000 \\
\text { employees }\end{array}$} & \multirow{6}{*}{ Private/Contractor } & \multirow{6}{*}{$\begin{array}{l}\text { Building } \\
\text { Civil \& Infrastructure } \\
\text { Commercial } \\
\text { Airport }\end{array}$} & \multirow{6}{*}{$\begin{array}{l}112 \text { years' experience in } \\
\text { the construction } \\
\text { industry }\end{array}$} & IC01 & High & All applied & \multirow{6}{*}{$\begin{array}{l}\text { Project 3: Main Highway } \\
\text { Upgrade and Bridge } \\
\text { Construction Project } \\
\text { Project 4: Airport Terminal } \\
\text { Expansion project }\end{array}$} \\
\hline & & & & & IC02 & High & All applied & \\
\hline & & & & & IC03 & Mid & Applied in most of the projects & \\
\hline & & & & & IC04 & Mid & $\begin{array}{l}\text { Technical training and ICT training available for } \\
\text { popular systems and can be provided for special } \\
\text { systems in request }\end{array}$ & \\
\hline & & & & & IC05 & Low & $\begin{array}{l}\text { Very basic support system / support system for all } \\
\text { ICT is outsourcing }\end{array}$ & \\
\hline & & & & & IC06 & High & $\begin{array}{l}\text { The company policy urge the ICT support to } \\
\text { provide the up to date version of all ICT tools } \\
\text { available with a regular check every } 6 \text { months }\end{array}$ & \\
\hline
\end{tabular}


Table 3 presents the ICT utilization and implementation for each case study. The ICT applications have been grouped into five main ICT application classifications, which can classify most of the ICT products in the construction industry as the following $[6,7,18,24,26]$ :

- Sharing tools, cloud storage, and web conferencing: this collection includes the communication technology tools which facilitate the organization or project communication and information sharing system.

- Job-site data collection and reporting: this collection covers the most common usage of software or tools in any project size, which involves the daily reporting support tools and can be used by non-professional construction teams.

- Computer-aided drafting (CAD): CAD systems provide drawing entities with powerful construction, editing, and database techniques to produce drawings and models of what buildings will look like when finished.

- Planning and project management: this collection covers software or tools that allow the managing of complicated business processes by planning, organizing, and managing the various resource pools available.

- $\quad$ Building information modeling (BIM): BIM software can directly and interactively present design concepts in a form that represents physical and real images of the building to allow designers to identify clients' needs and provide solutions to these needs promptly and effectively.

Table 3. List of ICT applications and categories implemented in each project case study.

\begin{tabular}{|c|c|c|}
\hline Project Name & List of By-Products Used in This Project & $\begin{array}{l}\text { List of Application Categories Used in } \\
\text { this Project }\end{array}$ \\
\hline Project1: Urban Road Upgrade & $\begin{array}{l}\text { Dropbox, Adobe Acrobat, Aconex } \\
\text { Microsoft Office Package, NoteVault } \\
\text { AutoCad, Navisworks, Tekla } \\
\text { Primavera, Microsoft Project, Syncro 4D } \\
\text { Planning } \\
\text { Deltek Vision }\end{array}$ & $\begin{array}{l}\text { Cloud Storage, Sharing, and Web } \\
\text { Conferencing } \\
\text { Job Site Data Collection \& Reporting } \\
\text { BIM and CAD } \\
\text { Planning and Project Management } \\
\text { Accounting }\end{array}$ \\
\hline $\begin{array}{l}\text { Project 2: Airport Network } \\
\text { Transportation Upgrade }\end{array}$ & $\begin{array}{l}\text { Adobe Acrobat, Aconex } \\
\text { Microsoft Office Package } \\
\text { AutoCad } \\
\text { Primavera, Microsoft Project, Deltek } \\
\text { Acumen } \\
\text { Deltek Vision }\end{array}$ & $\begin{array}{l}\text { Cloud Storage, Sharing, and Web } \\
\text { Conferencing } \\
\text { Job Site Data Collection \& Reporting } \\
\text { BIM and CAD } \\
\text { Planning and Project Management } \\
\text { Accounting }\end{array}$ \\
\hline $\begin{array}{l}\text { Project 3: Main Highway Upgrade and } \\
\text { Bridge Construction Project }\end{array}$ & $\begin{array}{l}\text { Adobe Acrobat, StoneX } \\
\text { Microsoft Office Package } \\
\text { AutoCad } \\
\text { Primavera, Microsoft Project, Deltek } \\
\text { Acumen } \\
\text { Planswift, Trimble Accubid } \\
\text { CMiC }\end{array}$ & $\begin{array}{l}\text { Cloud Storage, Sharing, and Web } \\
\text { Conferencing } \\
\text { Job Site Data Collection \& Reporting } \\
\text { BIM and CAD } \\
\text { Planning and Project Management } \\
\text { Estimating and Take-off Software } \\
\text { Accounting }\end{array}$ \\
\hline $\begin{array}{l}\text { Project 4: Airport Terminal Expansion } \\
\text { project }\end{array}$ & $\begin{array}{l}\text { Adobe Acrobat, Aconex } \\
\text { Microsoft Office Package } \\
\text { AutoCad, Navisworks } \\
\text { Primavera, Microsoft Project, Syncro 4D } \\
\text { Planning, Deltek Acumen } \\
\text { Planswift, Trimble Accubid } \\
\text { CMiC, Jonas Software } \\
\text { CYPE INGENIEROS }\end{array}$ & $\begin{array}{l}\text { Cloud Storage, Sharing, and Web } \\
\text { Conferencing } \\
\text { Job Site Data Collection \& Reporting } \\
\text { BIM and CAD } \\
\text { Planning and Project Management } \\
\text { Estimating and Take-off Software } \\
\text { Accounting } \\
\text { Building Engineering Application }\end{array}$ \\
\hline
\end{tabular}

\section{Discussion}

By analyzing the data collected in the previous sections and empirically assessing project performance of the case studies, it is observed that the "Airport Network Transportation Upgrade" (Project 2) had the best performance. For this project, the full delay period has been compensated, and according to the client, none of the delay reasons are the 
contractor's issue. However, according to Table 3, this project has utilized fewer categories of ICT.

Accordingly, the "Main Highway Upgrade and Bridge Construction" (project 3) has been identified as having the lowest project performance compared with the other cases in this study. Moreover, this case had the same structure of ICT utilization compared with project 2, "Airport Network Transportation Upgrade", which is also the lowest compared with the other cases in this study.

A numerical illustration of the combined case studies' information has been created and presented in a bubble chart format (Figure 7). This was to understand the alignment level between the ITC infrastructure for each project and the corresponding organizations, the ICT utilization in the projects, and the final project performance. It was done by considering the ICT infrastructure level in each organization, the ICT level of utilization in each project, and the final project performance and outcomes.

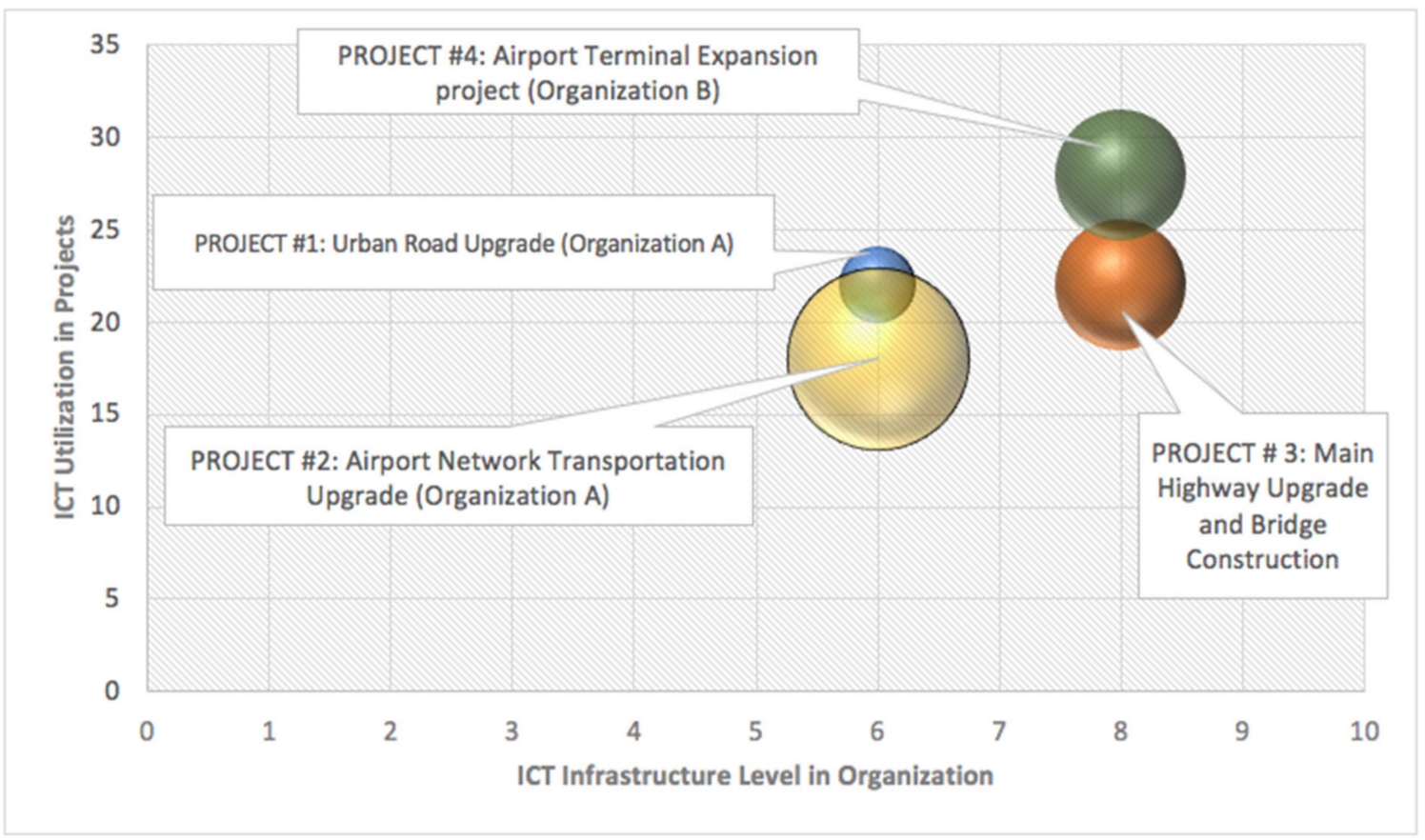

Figure 7. ICT infrastructure, ICT utilization, and project performance relationships.

Although the data collected from the case studies were in various forms and have been analyzed separately, the numerical conversion of this data was also very insightful. This is especially the case if the range of collected data is wide, and these data need to be studied together for a single result $[50,51,53,54]$. Hence, a scale was developed for ICT infrastructure classification from each organization and used in generating the bubble chart in Figure 7. Two points were assigned if the ICT infrastructure level in the organization is high, one point if this level is in the medium stage, and no points if the classification is low or does not exist; then, the total number of these points have been calculated from each organization and added to each project's case study depending on its organization.

The same concept has been applied to the ICT utilization in projects (Figure 7) to calculate the level of ICT implementation. However, both ICT categories and ICT products have been considered during the calculation process. Therefore, each ICT category implemented in the project will have three points, in addition to one more point for each additional ICT product in this category. Finally, the project performance value has been indicated with volume-based bubbles. The bubble that is largest in volume refers to the project highest in performance compared with the other case study projects.

Based on Figure 7, two cases in the study, project 4 (Airport Terminal Expansion Project) and project 3 (Main Highway Upgrade and Bridge Construction), have an acceptable 
alignment between their organization ICT infrastructure and the project ICT utilization, and at the same time, they have achieved an acceptable performance result. On the other hand, one of the cases in the study, project 2 (Airport Network Transportation Upgrade), has better performance outcomes than the previous cases in the study. However, it has been delivered using less alignment of ICT infrastructure and ICT utilization. By studying in detail the project conditions of these three cases based on the projects' history data, project 2 was delivered with 145 working days of delay. However, all the delay has been accepted by the client as a "compensable delay" due to the COVID-19 lockdown (the first lockdown period in New Zealand was from 25 March 2020 to 28 April 2020), which was only about 21 working days, and also due to an extension of the total work period requested by the client to redeliver the decreased scope of the project (the scope was decreased due to COVID-19's financial effect on the airport projects).

Looking at this project condition from the contractor's point of view, the project team received an extension of time exceeding the previous work period to deliver both the original scope and reduced scope of works compared with the tender phase's approved construction duration. Based on this, we cannot consider the non-compensable delays in this particular project as constituting a good project performance. The construction work productivity was not the main reason for these positive non-compensable delay outcomes. Conversely, the other two cases with good performance outcomes, project 4 (Airport Terminal Expansion Project) and project 3 (Main Highway Upgrade and Bridge Construction), had all the compensable delays purely as a result of a client design issue, work change request, additional works request, or client delay in response to a request for information.

Based on the findings, the good level of the strategic alignment between the organization's ICT infrastructure and the project's ICT utilization, as well as the level of the ICT implementation, could be one of the important factors that can facilitate project delivery and improve the project outcomes. However, as stated above, the performance of the project depends on many other factors, such as construction teams' experience, resource availability, subcontracting management, changes in management, project management level, project type, working conditions, and material availability. It cannot be assumed that the ICT strategic alignment level is the main reason for the high-performance or low-performance results. For instance, although the ICT utilization in project 3 (Main Highway Upgrade and Bridge Construction) is higher than in project 2 (Airport Network Transportation Upgrade), there was a huge non-compensable delay outcome in the construction phase of this project. By studying this project in detail, it has been found that delays were caused by issues such as a change in the organization structure or organization transfer, as the project was initially awarded to another organization and then reassigned. Moreover, the results from this study can be a reference for organizations' human resource management, considering more ICT positions in the project supporting the projects' delivery team. Accordingly, the application of decision support systems is on the rise within the construction sector. These systems rely heavily on ICT application and require specialized trained personnel [65].

Consequently, more empirical research is required on the alignment of organization ICT infrastructure and project ICT utilization, and their effects on construction performance. Finally, this research can analyze the effect of efficient ICT utilization on project performance in the construction industry, which leads to optimal strategic utilization. Construction organizations can use these empirical study results to deliver their products more efficiently, cheaper, and faster, and maintain stakeholders' satisfaction.

\section{Conclusions}

In this research, case studies have been diagnostically analyzed to investigate the effect of the strategic alignment between the organization's ICT infrastructure and the project's ICT utilization on the project performance. Four project cases have been selected in two large-sized organizations in Auckland, New Zealand, and historical data related to the project performance, project ICT implementation, and ICT infrastructure level from each 
organization have been collected. Thus, all the collected data have been organized into a bubble analysis histogram to compare and investigate the results related to the ICT and to the performance outcomes.

The findings have been analyzed and presented based on a multiple case study framework, which included review of project records and historical data. The strategic alignment between ICT infrastructure and ICT utilization can be one of the factors that can improve the final project performance, considering the best-case scenario in terms of the project conditions. Moreover, it has been recommended that more empirical research in the same field of study is required to obtain more accurate results answering the main research questions of this study.

In terms of the practical implications of this study, this research can be used to analyze the effect of efficient ICT utilization on project performance in the construction industry, which leads to optimal strategic utilization. Based on the approaches discussed, construction organizations can enhance strategic alignments between organizational infrastructure and actual ICT utilization. This enables organizations to better understand the functions of ICT tools and infrastructure in enhancing project performance. Conversely, the feedback from the case studies allows for the identification of less effective ICT infrastructure and can cater for more objective and project-based outcomes.

In addition, the issues of strategic ICT alignment have been investigated in construction for the first time. This adds to the body of knowledge on new technology applications and utilizations in construction. A method of evaluating and identifying ICT utilization and infrastructure has been proposed. This can be further explored in construction re-search using different research methodologies or the application of expansive empirical studies with different settings and study conditions.

For future research and education recommendations, an in-depth exploration of how ICT alignment with organization infrastructure can improve the outcomes of a project would be very helpful. Further research might compare, for instance, traditional management projects with modern or ICT-based management projects. Moreover, additional methodological work is needed on how ICT alignment with organizational infrastructure can impact the outcomes of projects. Other methodologies could include structured interviews or focus group gatherings with construction management experts. Although methodologically challenging, it would be very useful to conduct some longer-term studies, seeking to quantify the impact of ICT implementation on different types of construction projects and organizations at different size levels.

Finally, considering the research method, the scope of this study is limited to advanned large construction projects managed by large-sized construction organizations within New Zealand. The selection of the study cases in this research was based on organizations with ICT usage history and ability to provide strong ICT infrastructure.

Author Contributions: Conceptualization, H.K.E., M.B.J. and M.P.; methodology, H.K.E., M.B.J. and M.P.; formal analysis, H.K.E., M.B.J. and M.P.; investigation, H.K.E., M.B.J. and M.P.; resources, H.K.E., M.B.J. and M.P.; data curation, H.K.E., M.B.J. and M.P.; writing-original draft preparation, H.K.E.; writing-review and editing, H.K.E., M.B.J. and M.P.; visualization, H.K.E., M.B.J. and M.P.; supervision, M.B.J. and M.P.; All authors have read and agreed to the published version of the manuscript.

Funding: This research received no external funding.

Institutional Review Board Statement: This study has been evaluated and judged to be low risk by the Massey University Human Ethics Committee (MUHEC)- Ethics Notification Number: 4000022560.

Informed Consent Statement: Informed consent was obtained from all subjects involved in the study.

Data Availability Statement: The data presented in this study are available on request from the corresponding author. The data are not publicly available due to privacy concerns.

Conflicts of Interest: The authors declare no conflict of interest. 


\section{References}

1. The Ministry of Business, Innovation and Employment. Building and Construction Sector Trends Annual Report 2021; MBIE: Wellington, New Zealand, 2021.

2. Adafin, J.; Wilkinson, S.; Rotimi, J.O.B.; MacGregor, C.; Tookey, J.; Potangaroa, R. Creating a case for innovation acceleration in the New Zealand building industry. Constr. Innov. 2021, 22, 185-204. [CrossRef]

3. Eliwa, H.; Jelodar, M.B.; Poshdar, M. Information technology and New Zealand construction industry: An empirical study towards strategic alignment of project and organization. In Proceedings of the 18th International Conference on Construction Applications of Virtual Reality (CONVR2018), Auckland, New Zealand, 22-23 November 2018.

4. Harris, F.; McCaffer, R.; Baldwin, A.; Edum-Fotwe, F. Modern Construction Management; John Wiley \& Sons: Hoboken, NJ USA, 2021.

5. Alaloul, W.S.; Liew, M.S.; Zawawi, N.A.W.A.; Kennedy, I.B. Industrial Revolution 4.0 in the construction industry: Challenges and opportunities for stakeholders. Ain Shams Eng. J. 2020, 11, 225-230. [CrossRef]

6. Adriaanse, A.; Voordijk, H.; Dewulf, G. The use of interorganisational ICT in United States construction projects. Autom. Constr. 2010, 19, 73-83. [CrossRef]

7. Hosseini, R.; Chileshe, N.; Zou, J.; Baroudi, B. Approaches of implementing ICT technologies within the construction industry. In Proceedings of the 6th International Conference on the Built Environment in Developing Countries (ICBEDC), Adelaide, Australia, 4-5 December 2012.

8. Peansupap, V.; Walker, D.H. Information communication technology (ICT) implementation constraints: A construction industry perspective. Eng. Constr. Archit. Manag. 2006, 13, 365-379. [CrossRef]

9. Arayici, Y.; Aouad, G.; Ahmed, V. Requirements engineering for innovative integrated ICT systems for the construction industry. Constr. Innov. 2015, 5, 179-200. [CrossRef]

10. Serpell, A.; Barai, S.; Oladapo, A.A. An investigation into the use of ICT in the Nigerian construction industry. J. Inf. Technol. Constr. 2005, 12, 261-277.

11. Yanting, L. Cross-Sector Co-deployment of ICT Infrastructure with Other Sectors in China; CAICT: Beijing, China, 2018.

12. Wu, D.; Yu, X.; Zhu, S. A Study of the ICT Infrastructure in Education of South Korea. In Modern Distance Education Research 2014; Volume 5, pp. 86-94. Available online: https://www.oriprobe.com/journals/xdycjyyj/2014_6.html (accessed on 10 December 2021).

13. Hanafizadeh, M.R.; Saghaei, A.; Hanafizadeh, P. An index for cross-country analysis of ICT infrastructure and access. Telecommun Policy 2009, 33, 385-405. [CrossRef]

14. Eliwa, H.; Babaeian Jelodar, M.; Yi, W.; Poshdar, M. Information Technology Applications in Construction Organizations: A Systematic Review. In Proceedings of the 6th New Zealand Built Environment Research Symposium, Auckland, New Zealand, 26 February 2020.

15. Losurdo, F.; Dileo, I.; Siergiejczyk, M.; Krzykowska, K.; Krzykowski, M. Innovation in the ICT infrastructure as a key factor in enhancing road safety: A multi-sectoral approach. In Proceedings of the 2017 25th International Conference on Systems Engineering (ICSEng), Las Vegas, NV, USA, 22-24 August 2017.

16. Campbell, B.; Kay, R.; Avison, D. Strategic alignment: A practitioner's perspective. J. Enterp. Inf. Manag. 2005, 18, 653-664. [CrossRef]

17. Jelodar, M.B.; Shu, F. Innovative use of low-cost digitization for smart information systems in construction projects. Buildings 2021, 11, 270. [CrossRef]

18. Ezcan, V.; Goulding, J.S.; Arif, M. Redefining ICT embeddedness in the construction industry: Maximizing technology diffusion capabilities to support agility. Build. Res. Inf. 2020, 48, 922-944. [CrossRef]

19. McNamara, A.J.; S M Sepasgozar. Intelligent contract adoption in the construction industry: Concept development. Autom. Constr. 2021, 122, 103452. [CrossRef]

20. Moshood, T.; Nawanir, G.; Sorooshian, S.; Mahmud, F.; Adeleke, A. Barriers and benefits of ICT adoption in the nigerian construction industry. A comprehensive literature review. Appl. Syst. Innov. 2020, 3, 46. [CrossRef]

21. Schönbeck, P.; Löfsjögård, M.; Ansell, A. Quantitative review of construction 4.0 Technology presence in construction project research. Buildings 2020, 10, 173. [CrossRef]

22. Hou, L.; Wu, S.; Zhang, G.; Tan, Y.; Wang, X. Literature review of digital twins applications in construction workforce safety. Appl. Sci. 2021, 11, 339. [CrossRef]

23. Wu, H.; Shen, G.Q.; Lin, X.; Li, M.; Li, C.Z. A transformer-based deep learning model for recognizing communication-oriented entities from patents of ICT in construction. Autom. Constr. 2021, 125, 103608. [CrossRef]

24. Alsafouri, S.; Ayer, S.K. Review of ICT implementations for facilitating information flow between virtual models and construction project sites. Autom. Constr. 2018, 86, 176-189. [CrossRef]

25. Hasan, A.; Elmualim, A.; Rameezdeen, R.; Baroudi, B.; Marshall, A. An exploratory study on the impact of mobile ICT on productivity in construction projects. Built Environ. Proj. Asset Manag. 2018, 8, 320-332. [CrossRef]

26. Chipidza, W.; Leidner, D. A review of the ICT-enabled development literature: Towards a power parity theory of ICT4D. J. Strateg. Inf. Syst. 2019, 28, 145-174. [CrossRef]

27. Li, J.; Li, H.; Umer, W.; Wang, H.; Xing, X.; Zhao, S.; Hou, J. Identification and classification of construction equipment operators' mental fatigue using wearable eye-tracking technology. Autom. Constr. 2020, 109, 103000. [CrossRef] 
28. Allen, B. Broader outcomes in procurement policy-a case of New Zealand pragmatism. J. Public Procure. 2021, $21,318-341$. [CrossRef]

29. Sooriyamudalige, N.; Domingo, N.; Shahzad, W.; Childerhouse, P. Barriers and enablers for supply chain integration in prefabricated elements manufacturing in New Zealand. Int. J. Constr. Supply Chain Manag. 2020, 10, 73-91. [CrossRef]

30. Daniotti, B.; Gianinetto, M.; della Torre, S. Digital Transformation of the Design, Construction and Management Processes of the Built Environment; Springer Nature: Cham, Switzerland, 2020.

31. Wang, G.; Lu, H.; Hu, W.; Gao, X.; Pishdad-Bozorgi, P. Understanding Behavioral Logic of Information and Communication Technology Adoption in Small-and Medium-Sized Construction Enterprises: Empirical Study from China. J. Manag. Eng. 2020, 36, 05020013. [CrossRef]

32. Saka, A.B.; Chan, D.W. Profound barriers to building information modelling (BIM) adoption in construction small and mediumsized enterprises (SMEs): An interpretive structural modelling approach. Constr. Innov. 2020, 20, 261-284. [CrossRef]

33. Liu, B.; Yang, B.; Xiao, J.; Zhu, D.; Zhang, B.; Wang, Z.; Dong, M. Review of Optimization Dynamically Applied in the Construction and the Application Potential of ICT. Sustainability 2021, 13, 5478. [CrossRef]

34. Boton, C.; Kubicki, S.; Halin, G. The challenge of level of development in 4D/BIM simulation across AEC project lifecyle. A case study. Procedia Eng. 2015, 123, 59-67. [CrossRef]

35. Afzal, M.; Shafiq, M.T. Evaluating 4D-BIM and VR for Effective Safety Communication and Training: A Case Study of Multilingual Construction Job-Site Crew. Build. 2021, 11, 319. [CrossRef]

36. Howard, R.; Björk, B.-C. Building information modelling-Experts' views on standardization and industry deployment. Adv. Eng. Inform. 2008, 22, 271-280. [CrossRef]

37. Mesároš, P.; Behúnová, A.; Mandičák, T.; Behún, M.; Krajníková, K. Impact of enterprise information systems on selected key performance indicators in construction project management: An empirical study. Wirel. Netw. 2021, 27, 1641-1648. [CrossRef]

38. Lu, H.; Pishdad-Bozorgi, P.; Wang, G.; Xue, Y.; Tan, D. ICT implementation of small-and medium-sized construction enterprises: Organizational characteristics, driving forces, and value perceptions. Sustainability 2019, 11, 3441. [CrossRef]

39. Li, W.; Liu, K.; Belitski, M.; Ghobadian, A.; O’Regan, N. e-Leadership through strategic alignment: An empirical study of small-and medium-sized enterprises in the digital age. J. Inf. Technol. 2016, 31, 185-206. [CrossRef]

40. Henderson, J.C.; Venkatraman, H. Strategic alignment: Leveraging information technology for transforming organizations. IBM Syst. J. 1999, 38, 472-484. [CrossRef]

41. Henderson, J.C.; Venkatraman, N. Strategic alignment: A Model for Organizational Transformation via Information Technology; Oxford University Press: New York, NY, USA, 1994.

42. Wetering, R.; Mikalef, P.; Pateli, A. A strategic alignment model for IT flexibility and dynamic capabilities: Toward an assessment tool. In Proceedings of the 25th European Conference on Information Systems (ECIS), Guimarães, Portugal, 5-10 June 2017.

43. Burn, J.M.; Szeto, C. A comparison of the views of business and IT management on success factors for strategic alignment. Inf. Manag. 2000, 37, 197-216. [CrossRef]

44. Chi, M.; Huang, R.; George, J.F. Collaboration in demand-driven supply chain: Based on a perspective of governance and IT-business strategic alignment. Int. J. Inf. Manag. 2020, 52, 102062. [CrossRef]

45. Bhattacharya, P. Aligning enterprise systems capabilities with business strategy: An extension of the strategic alignment model (SAM) using enterprise architecture. Procedia Comput. Sci. 2018, 138, 655-662. [CrossRef]

46. Hinkelmann, K.; Pasquini, A. Supporting business and IT alignment by modeling business and IT strategy and its relations to enterprise architecture. In Proceedings of the 2014 Enterprise Systems Conference IEEE, Washington, DC, USA, 2-3 August 2014.

47. Beecroft, I.; Osabuohien, E.S.; Efobi, U.R.; Olurinola, I.; Osabohien, R.A. Manufacturing export and ICT infrastructure in West Africa: Investigating the roles of economic and political institutions. Inst. Econ. 2020, 12, 36.

48. Kurniawati, M.A. The role of ICT infrastructure, innovation and globalization on economic growth in OECD countries, $1996-2017$. J. Sci. Technol. Policy Manag. 2020, 11, 193-215. [CrossRef]

49. Nair, M.; Pradhan, R.P.; Arvin, M.B. Endogenous dynamics between R\&D, ICT and economic growth: Empirical evidence from the OECD countries. Technol. Soc. 2020, 62, 101315.

50. Pandey, P.; Pandey, M.M. Research Methodology Tools and Techniques; Bridge Center: Buzau, Romania, 2021.

51. Noor, K.B.M. Case study: A strategic research methodology. Am. J. Appl. Sci. 2008, 5, 1602-1604. [CrossRef]

52. Snyder, C. A case study of a case study: Analysis of a robust qualitative research methodology. Qual. Rep. 2012, 17, 26.

53. Johansson, R. On case study methodology. Open House Int. 2007, 32, 48-54. [CrossRef]

54. Meyer, C.B. A case in case study methodology. Field Methods 2001, 13, 329-352. [CrossRef]

55. Goldsmith, P. Fletchers: A Centennial History of Fletcher Building; Davia Ling Publishing: Auckland, New Zealand, 2019.

56. Smith, J. A History of Fletcher Construction; Steele Roberts: Wellington, New Zealand, 2009; Volume I, pp. $1909-1940$.

57. NZTA. SH16 Lincoln to Westgate Current and Future; NZTA: Auckland, New Zealand, 2016.

58. NZTA. SH16 Lincoln to Westgate Upgrade; NZTA: Auckland, New Zealand, 2019.

59. AIAL. Northern Network Project Upgrade; AIAL: Auckland, New Zealand, 2021.

60. Weeks, J. Auckland Airport: \$100 million for huge road project. Stuff News Network, 25 July 2019.

61. NZTA. SH16 Causeway Upgrade Project Master Plan-IFC; NZTA: Auckland, New Zealand, 2013.

62. NZTA. SH16 Causeway Upgrade Project Facts and Updates; NZTA: Auckland, New Zealand, 2016.

63. AIAL. Auckland Airport Development Projects; AIAL: Auckland, New Zealand, 2020. 
64. Bygstad, B.; Aanby, H.-P. ICT infrastructure for innovation: A case study of the enterprise service bus approach. Inf. Syst. Front. 2010, 12, 257-265. [CrossRef]

65. Jelodar, M.B.; Yiu, T.W.; Wilkinson, S. A Multi-Objective Decision Support System for Selecting Dispute Resolution Methods in the Construction Industry. In Proceedings of the 2014 International Conference on Computing in Civil and Building Engineering, Orlando, FL, USA, 23-25 June 2014; pp. 1642-1649. 